Received 15.03.2013 Reviewed 16.04.2013 Accepted 07.05.2013

A - study design B - data collection C - statistical analysis

D - data interpretation

E - manuscript preparation

F - literature search

\section{Calcium and magnesium uptake with the yield of meadow vegetation in relation to their content in atmospheric precipitation, ground water and soil solution}

\author{
Barbara SAPEK ${ }^{\text {ABCDEF }}$
}

Institute of Technology and Life Science, al. Hrabska 3, 05-090 Raszyn, Poland; tel. +48 22 735-75-66, e-mail: B.Sapek@itep.edu.pl

\begin{abstract}
For citation: Sapek B. 2013. Calcium and magnesium uptake with the yield of meadow vegetation in relation to their content in atmospheric precipitation, ground water and soil solution. Journal of Water and Land Development. No. 18 p. $73-83$
\end{abstract}

\begin{abstract}
The question was how and under which conditions the concentration and load of calcium and magnesium in atmospheric precipitation, ground water and soil solution may affect their uptake by vegetation in a managed meadow. The answer was based on results of $\mathrm{Ca}$ and $\mathrm{Mg}$ determinations in atmospheric fallout near Falenty, and in soil waters from two long-term meadow experiments on mineral soils situated in Masovian Province. Obtained results showed a complex effect of $\mathrm{Ca}$ and $\mathrm{Mg}$ deposition and associated effects of these components in ground water and soil solution on their uptake by plants due to fertilisation effect, harvesting and other factors of human impact. No distinctly positive effect was found of the increased deposition of Ca with atmospheric fallout on its uptake by plants on a long term basis. Such an effect was demonstrated for $\mathrm{Mg}$ load but only in very acidic soil. Under favourable physical and water conditions and at weakly acidic soil pH this effect was negative. The enrichment of ground water in Ca was accompanied by the increase of its uptake by plants and, at the same time, by the decrease of $\mathrm{Mg}$ uptake from very acidic soil. Under such soil $\mathrm{pH}$, decreased $\mathrm{Ca}$ uptake was associated with its higher concentration in soil solution. Neutralization of soil acidity facilitated the increased Mg concentration in soil solution and its decreased uptake by plants. Obtained results inspire to undertake similar studies in natural grassland ecosystems and in the so-called lands of ecological use.
\end{abstract}

Key words: atmospheric precipitation, calcium, ground water, magnesium, soil solution, uptake with meadow plant yield

\section{INTRODUCTION}

Plants ability to take up nutrients through their above-ground parts used in foliar fertilisation is a way of feeding plants more and more often used in grasslands [JANKOWSKA-HUFLEJT 2009; SKURZYŃSKI 2009]. Therefore, nutrient load deposited directly on plants and soil by atmospheric precipitation may, under specific conditions, significantly affect their content in and uptake with the yield. At a lack or deficit of nutrients in soil, atmospheric precipitation may be a source sustaining the development or regeneration of natural ecosystems as shown e.g. by SCHLESINGER et al. [1982], ARIANOUTSOU [1989], and CHADWICK et al. [1999]. The content of calcium and magnesium in precipitation, mainly neutralising the excess of acid-forming ions, may largely affect the fertility of natural ecosystems and nutrient uptake by plants. Acid rains may in turn accelerate nutrient washout from above-ground plant parts, mainly leaves, which are a source of regeneration of ecosystem fertility [POTTER et al. 1991]. An assessment of the role of atmos- 
pheric nutrient deposition in maintaining fertility found in the literature pertains mainly to forest ecosystems [JONARD et al. 2009; POTTER et al. 1991] including natural evergreen shrubs SCHLESINGER et al. [1982], ARIANOUTSOU [1989]. Due to permanent soil cover by sward, permanent grasslands are equally efficient absorbers of atmospheric nutrient deposits which secures the maintenance and development of natural grassland ecosystems. KACORZYK et al. [2012] showed that nutrient load including that of calcium and magnesium $\left(35.5 \mathrm{~kg} \mathrm{Ca} \cdot \mathrm{ha}^{-1}\right.$ and $3.4 \mathrm{~kg} \mathrm{Mg} \cdot \mathrm{ha}^{-1}$ on average) delivered with atmospheric fallout to mountain grasslands provides hay production of 1.5 $2.0 \mathrm{t} \cdot \mathrm{ha}^{-1}$.

Atmospheric fallout is one of the supplies of soil water phase composed of ground water and soil solution and being a source of plant feeding. Fertility of this phase will depend, among others, on chemical composition of precipitation. Soil waters are the source of soluble nutrients including calcium and magnesium [PRUSINKIEWICZ 2011; SZPERLIŃSKI 2002]. Availability of these components to and their uptake by plants depends on their content in soil solution [PRUSIŃKIEWICZ 2011; WARCHAŁOWA 1976]. In the earlier paper SAPEK [2011] estimated the dynamics of calcium and magnesium uptake by plants in long-term meadow experiments and compared it with the washout of $\mathrm{Ca}$ and $\mathrm{Mg}$ from soil, $\mathrm{pH}$ and the form of nitrogen fertiliser considering the effect of soil neutralisation with calcium fertilisers. This paper is an advancement of presented problems.

The aim of this study was to answer the question if, how and under which conditions the load of calcium and magnesium in atmospheric fallout, ground water and soil solution may affect their uptake by grassland vegetation.

\section{MATERIAL AND METHODS}

The study was based on two long-term meadow experiments situated in Masovian Province in Janki (J) and Laszczki (L) established in 1981 and 1982, respectively. An after-effect of liming and application of ammonium and calcium saltpetre on soil and vegetation and on nutrient release and ground water quality was evaluated.

Experiment was set up on very acid $\left(\mathrm{pH}_{\mathrm{KCl}}: \mathrm{J}-\right.$ 4.5, $\mathrm{L}$ - 4.3) mineral soils differing in the organic matter content $\left(\mathrm{C}_{\text {org }}: \mathrm{J}-19.0, \mathrm{~L}-38.0 \mathrm{~g} \cdot \mathrm{kg}^{-1}\right)$, calcium $\left(\mathrm{Ca}_{\mathrm{tot}}: \mathrm{J}-1.44, \mathrm{~L}-2.58 \mathrm{~g} \cdot \mathrm{kg}^{-1}\right)$, magnesium $\left(\mathrm{Mg}_{\text {tot }}: \mathrm{J}-0.47, \mathrm{~L}-0.89 \mathrm{~g} \cdot \mathrm{kg}^{-1}\right)$ and the content of particles $<0.02 \mathrm{~mm}(\mathrm{~J}-18.4, \mathrm{~L}-22.4 \%)$, and moisture ( $\mathrm{J}-22.1 \%$ vol., $\mathrm{L}-26.6 \%$ vol.).

Experiment was designed with the random block method in four repetitions with 6 distinguished fertilisation variants fertilised with a constant dose of phosphorus $\left(34.9 \mathrm{~kg} \mathrm{P} \cdot \mathrm{ha}^{-1}\right)$ and potassium $\left(125 \mathrm{~kg} \mathrm{~K} \cdot \mathrm{ha}^{-1}\right)$. Variants were not limed $\left(\mathrm{Ca}_{0}\right)$ or limed once in the beginning of experiment (1981/1982) with a single or double dose of calcium carbonate calculated according to the criterion of hydrolytic acidity $1 \mathrm{Hh}$ and $2 \mathrm{Hh}$ $\left(\mathrm{Ca}_{1}, \mathrm{Ca}_{2}\right)$. Study objects were fertilised with nitrogen at a dose of 120 and $240 \mathrm{~kg} \mathrm{~N} \cdot \mathrm{ha}^{-1}\left(\mathrm{~N}_{1}, \mathrm{~N}_{2}\right)$ in three parts under each cut in a form of ammonium saltpetre (AN) and since 1992, in parallel, on a half of $50 \mathrm{~m}^{2}$ plots - with calcium saltpetre $(\mathrm{CN})$.

Since 2000 phosphorus fertilisation was abandoned in both experiments to assess a possibility of limitation of $\mathrm{P}$ release to the environment. Experiments carried out according to this scheme were ended in 2007. Due to a change in the experimental project in Laszczki, harvesting was abandoned there since 2004. Detailed description of the experiments and fertilisation variants are given in SAPEK [2006] and SAPEK and SAPEK [2011]. Results of analyses from four variants: $\mathrm{Ca}_{0} \mathrm{~N}_{2} \mathrm{AN}, \mathrm{Ca}_{0} \mathrm{~N}_{2} \mathrm{CN}, \mathrm{Ca}_{2} \mathrm{~N}_{2} \mathrm{AN}$, $\mathrm{Ca}_{2} \mathrm{~N}_{2} \mathrm{CN}$ were used in this study. Soils from these experimental variants differed in $\mathrm{pH}_{\mathrm{KCl}}$ (Tab. 1).

Table 1. Mean $\mathrm{pH}_{\mathrm{KCl}}$ of the $0-10 \mathrm{~cm}$ soil layer from four fertilisation variants of meadow experiments in the years 1995-2007

\begin{tabular}{|l|c|c|c|c|c|}
\hline \multirow{2}{*}{ Experiment } & \multirow{2}{*}{ Value } & \multicolumn{4}{|c|}{ Soil $\mathrm{pH}_{\mathrm{KCl}}$} \\
\cline { 3 - 6 } & & $\mathrm{Ca}_{0} \mathrm{~N}_{2} \mathrm{AN}$ & $\mathrm{Ca}_{2} \mathrm{~N}_{2} \mathrm{AN}$ & $\mathrm{Ca}_{0} \mathrm{~N}_{2} \mathrm{CN}$ & $\mathrm{Ca}_{2} \mathrm{~N}_{2} \mathrm{CN}$ \\
\hline \multirow{2}{*}{ Janki } & mean & 3.6 & 4.3 & 5.0 & 6.6 \\
\cline { 2 - 6 } & $\mathrm{CV} \%$ & 5.1 & 11.67 & 12.0 & 3.6 \\
\hline \multirow{2}{*}{ Laszczki } & mean & 3.6 & 5.8 & 5.5 & 6.9 \\
\cline { 2 - 6 } & $\mathrm{CV} \%$ & 9.1 & 9.6 & 9.3 & 5.7 \\
\hline
\end{tabular}

Explanations: $\mathrm{Ca}_{0} \mathrm{~N}_{2} \mathrm{AN}, \mathrm{Ca}_{2} \mathrm{~N}_{2} \mathrm{AN}, \mathrm{Ca}_{0} \mathrm{~N}_{2} \mathrm{CN}, \mathrm{Ca}_{2} \mathrm{~N}_{2} \mathrm{CN}$ : $\mathrm{Ca}_{0}-$ not limed variants, $\mathrm{Ca}_{2}-$ limed variants, $\mathrm{N}_{2}-$ fertilisation with $240 \mathrm{~kg}$ $\mathrm{N} \cdot \mathrm{ha}^{-1}$ in a form of ammonium saltpetre $-\mathrm{AN}$ and calcium saltpetre $-\mathrm{CN} ; \mathrm{Ca}_{0} \mathrm{~N}_{2} \mathrm{CN}, \mathrm{Ca}_{2} \mathrm{~N}_{2} \mathrm{CN}-$ mean for the years $2000-2007 \mathrm{CV} \%-$ coefficient of variability.

Atmospheric fallout was sampled in Falenty and represented wet precipitation, both rain and snow [SAPEK 2011]. Sampling methods, analyses and other data on atmospheric precipitation collected from meteorological station situated near experimental fields in Falenty are given in SAPEK et al. [2003] and in SAPEK and NAWALANY [2006]. Mean precipitation for presented study periods (Tab. 2) are given in this paper. Samples of ground water were taken from wells installed in buffer zones of experiments. The description of sampling sites, sampling protocol and frequency is given in SAPEK et al. [2003] and SAPEK [2006].

Table 2. Annual mean atmospheric precipitation near Falenty in selected periods of meadow experiments

\begin{tabular}{|l|r|r|r|r|r|r|}
\hline \multirow{2}{*}{$\begin{array}{c}\text { Precipitation } \\
\text { mm }\end{array}$} & \multicolumn{7}{|c|}{ Years } \\
\cline { 2 - 7 } & $\begin{array}{c}1988- \\
2007\end{array}$ & $\begin{array}{c}1992- \\
2007\end{array}$ & $\begin{array}{c}2000- \\
2007\end{array}$ & $\begin{array}{c}1988- \\
2003\end{array}$ & $\begin{array}{c}1992- \\
2003\end{array}$ & $\begin{array}{c}2000- \\
2003\end{array}$ \\
\hline Mean & 518.5 & 531.0 & 523.0 & 505.3 & 517.6 & 475.0 \\
\hline SD & 79.4 & 84.3 & 94.8 & 77.0 & 85.9 & 96.5 \\
\hline CV\% & 15.3 & 15.9 & 18.1 & 15.2 & 16.6 & 20.3 \\
\hline
\end{tabular}

Explanations: $S D$ - standard deviation, $\mathrm{CV} \%$ - as in Table 1. Source: SAPEK and NAWALANY [2006]. 
Soil solutions were taken from the experiment in Janki where suction apparatuses were installed in the four mentioned above fertilisation objects. The method of sampling soil solutions with suction apparatuses equipped with pore cups and the way of calculating the washout of soil components can be found in SAPEK and PietrZaK [1996] and PietrzaK et al. [2006]. Calcium and magnesium was determined with the atomic absorption spectrophotometric method [SAPEK 1979].
The amount of calcium and magnesium taken up by dry plant yield in selected study periods was estimated and expressed as percent of atmospheric load of these elements. Mean uptake of the elements from variants $\mathrm{AN}$ and $\mathrm{CN}$ was taken for comparisons. Calcium input with superphosphate and calcium saltpetre was accounted for in calculations (Tabs 3-6). Due to abundant but non-homogenous results, the relationships between calcium and magnesium uptake and their content in atmospheric precipitation, ground wa-

Table 3. Calcium input with precipitation and superphosphate and its uptake by plants (mean from fertilisation variants) fertilised with ammonium saltpetre (AN) and calcium saltpetre $(\mathrm{CN})$ at a rate of $240 \mathrm{~kg} \mathrm{~N} \cdot \mathrm{ha}^{-1}$ in the Janki experiment

\begin{tabular}{|c|c|c|c|}
\hline \multirow{2}{*}{ Specification } & \multirow{2}{*}{ Years } & \multicolumn{2}{|c|}{ Amount } \\
\hline & & $\mathrm{kg} \cdot \mathrm{ha}^{-1} \cdot \mathrm{y}^{-1}$ & $\%$ \\
\hline \multicolumn{4}{|c|}{ AN fertilisation } \\
\hline $\mathrm{Ca}$ (I) from precipitation & $1988-2007$ & 17.4 & \\
\hline $\mathrm{Ca}$ (II) from precipitation & $2000-2007$ & 17.4 & \\
\hline $\mathrm{Ca}$ (I) uptake by plants & 1988-2007 & 30.1 & \\
\hline $\mathrm{Ca}$ (II) uptake by plants after the abandonment of P fertilisation in 2000 & $2000-2007$ & 24.7 & \\
\hline Contribution of atmospheric Ca I to Ca I uptake by plants & 1988-2007 & & 57.7 \\
\hline Contribution of atmospheric Ca II to Ca II uptake by plants & $2000-2007$ & & 70.6 \\
\hline Ca input with superphosphate & $1988-2007$ & 46.1 & \\
\hline Atmospheric $\mathrm{Ca}$ I compared with $\mathrm{Ca}$ from superphosphate & $1988-2007$ & & 37.7 \\
\hline \multicolumn{4}{|c|}{ CN fertilisation } \\
\hline $\mathrm{Ca}(\mathrm{I})$ from precipitation & $1992-2007$ & 18.2 & \\
\hline $\mathrm{Ca}(\mathrm{II})$ from precipitation & $2000-2007$ & 17.4 & \\
\hline $\mathrm{Ca}(\mathrm{I})$ uptake by plants & $1992-2007$ & 33.9 & \\
\hline $\mathrm{Ca}$ (II) uptake by plants after the abandonment of P fertilisation in 2000 & $2000-2007$ & 37.5 & \\
\hline Contribution of atmospheric Ca I to Ca I uptake by plants & $1992-2007$ & & $\overline{53.6}$ \\
\hline Contribution of atmospheric Ca II to Ca II uptake by plants & $2000-2007$ & & 46.3 \\
\hline Ca input with superphosphate & $1992-2007$ & 46.1 & \\
\hline Atmospheric Ca I compared with Ca from superphosphate & & & 39.5 \\
\hline Ca input with $\mathrm{CN}(\mathrm{kg} / \mathrm{ha})$ & $1992-2007$ & 343.0 & \\
\hline Atmospheric Ca I compared with $\mathrm{Ca}$ from CN & & & 5.3 \\
\hline
\end{tabular}

Table 4. Calcium input with precipitation and superphosphate and its uptake by plants (mean from fertilisation variants) fertilised with ammonium saltpetre (AN) and calcium saltpetre $(\mathrm{CN})$ at a rate of $240 \mathrm{~kg} \mathrm{~N} \cdot \mathrm{ha}^{-1}$ in the Laszczki experiment

\begin{tabular}{|c|c|c|c|}
\hline \multirow{2}{*}{ Specification } & \multicolumn{3}{|c|}{ Amount } \\
\hline & Years & $\mathrm{kg} \cdot \mathrm{ha}^{-1} \cdot \mathrm{y}^{-1}$ & $\%$ \\
\hline \multicolumn{4}{|c|}{ AN fertilisation } \\
\hline $\mathrm{Ca}(\mathrm{I})$ from precipitation & $1988-2003$ & 17.9 & \\
\hline $\mathrm{Ca}$ (II) from precipitation & $2000-2003$ & 19.4 & \\
\hline $\mathrm{Ca}(\mathrm{I})$ uptake by plants & $1988-2003$ & 46.8 & \\
\hline $\mathrm{Ca}$ (II) uptake by plants after the abandonment of P fertilisation in 2000 & $2000-2003$ & 54.2 & \\
\hline Contribution of atmospheric $\mathrm{Ca}$ I to $\mathrm{Ca}$ I uptake by plants & $1988-2003$ & & 38.2 \\
\hline Contribution of atmospheric Ca II to Ca II uptake by plants & $2000-2003$ & & 35.9 \\
\hline Ca input with superphosphate & 1988-2003 & 46.1 & \\
\hline Atmopheric Ca I compared with Ca from superphosphate & & & 38.8 \\
\hline \multicolumn{4}{|c|}{ CN ferilisation } \\
\hline Ca I from precipitation & $1992-2003$ & 19.1 & \\
\hline $\mathrm{Ca}(\mathrm{II})$ from precipitation & $2000-2003$ & 19.5 & \\
\hline $\mathrm{Ca}(\mathrm{I})$ uptake by plants & $1992-2003$ & 46.5 & \\
\hline $\mathrm{Ca}$ (II) uptake by plants after the abandonment of P fertilisation in 2000 & $2000-2003$ & 67.2 & \\
\hline Contribution of atmospheric Ca I to Ca I uptake by plants & $1992-2003$ & & 41.1 \\
\hline Contribution of atmospheric Ca II to Ca II uptake by plants & $2000-2003$ & & 29.0 \\
\hline Ca input with superphosphate & $1992-2003$ & 46.1 & \\
\hline Atmospheric Ca I compared with Ca from superphosphate & & & 41.4 \\
\hline Ca input from $\mathrm{CN}$ & $1992-2003$ & 343.0 & \\
\hline Atmospheric $\mathrm{Ca}$ I compared with $\mathrm{Ca}$ from $\mathrm{CN}$ & & & 5.6 \\
\hline
\end{tabular}


Table 5. Magnesium input with precipitation and its uptake by plants (mean from fertilisation variants) fertilised with ammonium saltpetre (AN) and calcium saltpetre at a rate of $240 \mathrm{~kg} \mathrm{~N} \cdot \mathrm{ha}^{-1}$ in the Janki experiment

\begin{tabular}{|c|c|c|c|}
\hline \multirow{2}{*}{ Specification } & \multicolumn{3}{|c|}{ Amount } \\
\hline & Years & $\mathrm{kg} \cdot \mathrm{ha}^{-1} \cdot \mathrm{y}^{-1}$ & $\%$ \\
\hline \multicolumn{4}{|c|}{ AN fertilisation } \\
\hline Mg I from precipitation & $1988-2007$ & 2.4 & \\
\hline Mg II from precipitation & $2000-2007$ & 2.4 & \\
\hline Mg I uptake by plants & $1988-2007$ & 7.8 & \\
\hline Mg II uptake by plants after the abandonment of P fertilisation since 2000 & $2000-2007$ & 6.9 & \\
\hline Contribution of atmospheric Mg I to Mg I uptake by plants & $1988-2007$ & & 30.8 \\
\hline Contribution of atmospheric Mg II to $\mathrm{Mg}$ II uptake by plants & $2000-2007$ & & 34.8 \\
\hline \multicolumn{4}{|l|}{$\begin{array}{ll} & \text { CN fertilisation } \\
\end{array}$} \\
\hline $\mathrm{Mg}$ I from precipitation & $1992-2007$ & 3.0 & \\
\hline Mg II from precipitation & $2000-2007$ & 2.4 & \\
\hline Mg I uptake by plants & $1992-2007$ & 5.8 & \\
\hline Mg II uptake by plants after the abandonment of P fertilisation since 2000 & $2000-2007$ & 5.2 & \\
\hline Contribution of atmospheric $\mathrm{Mg}$ I to $\mathrm{Mg}$ I uptake by plants & $1992-2007$ & & 51.7 \\
\hline Contribution of atmospheric $\mathrm{Mg}$ II to $\mathrm{Mg}$ II uptake by plants & $2000-2007$ & & 46.1 \\
\hline
\end{tabular}

Table 6. Magnesium input with precipitation and its uptake by plants (mean from fertilisation variants) fertilised with ammonium saltpetre $(\mathrm{AN})$ and calcium saltpetre $(\mathrm{CN})$ at a rate of $240 \mathrm{~kg} \mathrm{~N} \cdot \mathrm{ha}^{-1}$ in the Laszczki experiment

\begin{tabular}{|c|c|c|c|}
\hline \multirow{2}{*}{ Specification } & \multicolumn{3}{|c|}{ Amount } \\
\hline & Years & $\mathrm{kg} \cdot \mathrm{ha}^{-1} \cdot \mathrm{y}^{-1}$ & $\%$ \\
\hline \multicolumn{4}{|c|}{ AN fertilisation } \\
\hline Mg I from precipitation & 1988-2003 & 2.4 & \\
\hline Mg II from precipitation & $2000-2003$ & 2.4 & \\
\hline Mg I uptake by plants & $1988-2003$ & 16.0 & \\
\hline Mg II uptake by plants after the abandonment of P fertilisation since 2000 & $2000-2003$ & 15.3 & \\
\hline Contribution of atmospheric $\mathrm{Mg}$ I to Mg I uptake by plants & $1988-2003$ & & $\mathbf{1 5 . 0}$ \\
\hline Contribution of atmospheric $\mathrm{Mg}$ II to $\mathrm{Mg}$ II uptake by plants & $2000-2003$ & & 15.7 \\
\hline \multicolumn{4}{|l|}{$\begin{array}{ll} & \text { CN fertilisation } \\
\end{array}$} \\
\hline Mg I from precipitation & $1992-2003$ & 2.4 & \\
\hline Mg II from precipitation & $2000-2003$ & 2.4 & \\
\hline Mg I uptake by plants & $1992-2003$ & 15.6 & \\
\hline $\mathrm{Mg}$ (II) uptake by plants after the abandonment of P fertilisation since 2000 & $2000-2003$ & 15.5 & \\
\hline Contribution of atmospheric $\mathrm{Mg}$ I to $\mathrm{Mg}$ I uptake by plants & $1992-2003$ & & $\mathbf{1 5 . 4}$ \\
\hline Contribution of atmospheric Mg II to Mg II uptake by plants & $2000-2003$ & & $\mathbf{1 5 . 5}$ \\
\hline
\end{tabular}

ter and soil solution were tested with non-parametric Spearman rank correlation test and expressed as Spearman correlation coefficient $\left(r_{s}\right)$.

\section{RESULTS AND DISCUSSION}

\section{CALCIUM AND MAGNESIUM IN WET PRECIPITATION AND THEIR UPTAKE BY PLANTS}

Comparison of calcium and magnesium loads deposited on the surface of mown meadows with the amount of these components taken up by plants was not aimed to assess their real uptake from rainfall. This would need specific radioisotope methods. The comparison provides, however, information on a possible effect and importance of natural sources of the two elements. The need of balancing nutrient loads delivered to natural ecosystems was expressed e.g. by ARIANOUTSOU [1989] who assessed productivity and nutrient cycling in natural scrublands in northeastern Greece (maquis) and by SCHLESINGER et al. [1982] who studied nutrient losses in the surface runoff from chaparral (southern California) after fire. Also JONARD et al. [2009], based on forest monitoring in France, Walloon and Luxemburg, underlined the need of the assessment of nutrients deposited by precipitation to establish feeding status of forest tree stands.

Calcium. The proportion of calcium load from precipitation to its amount taken up by meadow vegetation differed in relation to soil properties, type and dose of nitrogen fertiliser and to the presence or absence of $\mathrm{P}$ fertilisation (Tab. 3, 4). In the case of less fertile and drier soil in Janki, atmospheric Ca load constituted $57.7 \%$ of $\mathrm{Ca}$ taken up annually by plants fertilised with ammonium saltpetre. After the abandonment of fertilisation with superphosphate (which enriched the soil in $\mathrm{Ca}$ itself) the percent increased to $70.6 \%$. Atmospheric $\mathrm{Ca}$ load equalled $37.7 \%$ of the amount annually delivered to the soil with superphosphate (Tab. 3). When the soil was fertilised with calcium saltpetre (the years 1992-2007) the share of atmospheric $\mathrm{Ca}$ in plant uptake slightly decreased to 
$53.6 \%$. However, annual input of $342.8 \mathrm{~kg} \mathrm{Ca} \cdot \mathrm{ha}^{-1}$ with calcium saltpetre and parallel abandonment of phosphorus fertilisation decreased the contribution of atmospheric $\mathrm{Ca}$ to plant uptake to $46.3 \%$. In the case of $\mathrm{CN}$ fertilisation, atmospheric Ca load (5.6\%) was of negligible importance (Tab. 3).

More favourable soil-water conditions in the experiment in Laszczki, particularly higher content of soil $\mathrm{Ca}$ (resulting in bigger yielding) markedly decreased the impact of atmospheric $\mathrm{Ca}$ on plant uptake (Tab. 4). The proportion of atmospheric calcium to the amount taken up by plants in this experiment was similar at both forms of nitrogen fertilisation (AN $38.2 \%$ and $\mathrm{CN}-41.1 \%$ ). The abandonment of $\mathrm{P}$ fertilisation, especially with the application of AN, did not exert a significant effect on the above proportions $(38.2 \%$ and $35.9 \%)$. Study period in this experiment was by 4 years shorter which might possibly affect the obtained results.

Magnesium. Atmospheric load of magnesium in the Janki experiment at AN and P fertilisation constituted $30.8 \%$ of its amount taken up by plant yield (Tab. 5). After the abandonment of P fertilisation the respective share was $34.8 \%$. As in the case of calcium, application of $\mathrm{CN}$ and no $\mathrm{P}$ fertilisation increased the share of atmospheric $\mathrm{Mg}$ in the amount of the element taken up by plants to ca $50 \%$ (Tab. 3,5 ). In more fertile and richer in magnesium soil in the Laszczki experiment, the share of atmospheric $\mathrm{Mg}$ load in plant uptake was ca $15 \%$ (Tab. 6). Moreover, in contrast with weaker and poorer in $\mathrm{Mg}$ soil in the Janki experiment, both the applied form of nitrogen fertiliser ( $\mathrm{AN}$ and $\mathrm{CN}$ ) and the abandonment of $\mathrm{P}$ fertilisation had no significant effect on the contribution of atmospheric Mg load (Tab. 6).

\section{THE RELATIONSHIP BETWEEN CALCIUM AND MAGNESIUM UPTAKE BY PLANTS AND THEIR CONCENTRATIONS AND LOADS IN WET PRECIPITATION}

Due to abandoned harvesting in the Laszczki experiment after 2003, calcium and magnesium uptake by plants from the two experiments and the concentrations and loads of these elements in atmospheric precipitation were taken from the years 1988-2003 when objects fertilised with ammonium saltpetre were compared. Comparisons between the objects fertilised with calcium and ammonium saltpetre refer to data from the years 1995-2003. Changes in $\mathrm{Ca}$ and $\mathrm{Mg}$ uptake by plants and in concentrations of both elements in precipitation were presented based on data from objects of most extreme $\mathrm{pH}$ values and fertilised with AN in the Laszczki experiment (Fig. 1a-d). Most statistically significant relationships were found just under such conditions. Other results pertaining to AN fertilised objects in Janki and to those fertilised with $\mathrm{CN}$ in both experiments are discussed only in the text.
Significant decrease of $\mathrm{Ca}$ uptake with time was found only for very acid $\left(\mathrm{Ca}_{0} \mathrm{~N}_{2} \mathrm{AN}-r_{s 2}=-0.59^{*}\right)$ and acid $\left(\mathrm{Ca}_{2} \mathrm{~N}_{2} \mathrm{AN}-r_{s 2}=-0.61^{* *}\right)$ soil fertilised with AN in Janki. In the Laszczki experiment a significant decrease of Mg uptake with time was noted in fertilisation variant $\mathrm{Ca}_{2} \mathrm{~N}_{2} \mathrm{AN}\left(r_{s 2}=-0.52^{*}\right)$ in the soil of $\mathrm{pH}$ optimum for grasslands $\left(\mathrm{pH}_{\mathrm{KCl}}=5.9\right)($ Tab. 1 , Fig. 1d). Fertilisation with $\mathrm{CN}$ and decreasing soil acidity facilitated the decreased $\mathrm{Mg}$ uptake by plants in the Janki experiment $\left(\mathrm{Ca}_{0} \mathrm{~N}_{2} \mathrm{CN}-r_{s 2}=-0.63^{*}\right.$ and $\left.\mathrm{Ca}_{2} \mathrm{~N}_{2} \mathrm{CN}-r_{s 2}=-0.66^{*}\right)$ but resulted in the increased $\mathrm{Ca}$ uptake in the Laszczki experiment $\left(\mathrm{Ca}_{0} \mathrm{~N}_{2} \mathrm{CN}-r_{s 2}\right.$ $=0.76^{* *}$ ) with time. In other variants no significant temporal changes in the uptake of analysed elements were noted.

In the study period 1988-2003 the concentration and load of $\mathrm{Ca}$ in atmospheric precipitation near $\mathrm{Fa}$ lenty were fairly stable while those of $\mathrm{Mg}$ significantly increased with time $\left(r_{1}=0.62^{*}, r_{1 b i s}=0.56^{*}\right)$. The course and direction of changes in the concentrations and loads of both elements are presented in Fig. 1a-d.

To answer the question put at the end of introduction, a search was undertaken for statistically significant correlations between the concentration or load of $\mathrm{Ca}$ and $\mathrm{Mg}$ in precipitation near Falenty and the uptake of these elements by meadow vegetation at different soil $\mathrm{pH}$ in four fertilisation variants fertilised with two forms of saltpetre. Expected result was found only in four cases in the Laszczki experiment. In acid soil of the variant $\mathrm{Ca}_{0} \mathrm{~N}_{2} \mathrm{AN}\left(\mathrm{pH}_{\mathrm{KCl}}=3.6\right)$ an increased load of $\mathrm{Mg}$ in precipitation was accompanied by a greater $\mathrm{Mg}$ uptake by plants $\left(r_{3 b i s}=0.48^{*}\right)$ (Fig. 1b). In the variant $\mathrm{Ca}_{2} \mathrm{~N}_{2} \mathrm{AN}\left(\mathrm{pH}_{\mathrm{KCl}}=5.8\right)$, significant negative correlation was found, however, between both $\mathrm{Mg}$ concentration and load in atmospheric precipitation and the uptake of this element by plants $\left(r_{3}=-0.55^{*}, r_{3 \mathrm{bis}}=-0.52^{*}\right.$, respectively) (Tab. 1, Fig. 1d). In the soil fertilised with calcium saltpetre $\left(\mathrm{Ca}_{2} \mathrm{~N}_{2} \mathrm{CN}\right)$ an increased load of $\mathrm{Ca}$ in precipitation significantly increased $\mathrm{Ca}$ uptake by plants $\left(r_{3 b i s}=\right.$ $\left.0.65^{*}\right)$. One may expect that the negative correlation between $\mathrm{Mg}$ load and uptake is associated with a complex interaction of calcium compounds differing in solubility which, apart from $\mathrm{Mg}$, are the components of atmospheric precipitation. Calcium compounds may weaken $\mathrm{Mg}$ absorption by plants which was demonstrated by HAWLICZKA et al. [2003]. The authors underlined a complex effect of the form and solubility of calcium and magnesium compounds present in atmospheric fallout on the environmental behaviour of these elements. Despite higher content of $\mathrm{Ca}$ in precipitation, its soluble forms exert smaller effect on rain $\mathrm{pH}$ than magnesium [HAWLICZKA et al. 2003]. Therefore, the rainfall becomes more acid with increasing $\mathrm{Mg}$ content, which in turn facilitates washing out of $\mathrm{Mg}$ from soil and meadow sward and consequently decreases its uptake by plant yield. 
a) $\mathrm{Ca}_{0} \mathrm{~N}_{2} \mathrm{AN}$

$r_{s 1}, r_{s 1 b i s}, r_{s 2}, r_{s 3}, r_{s 3 b i s}-n i$

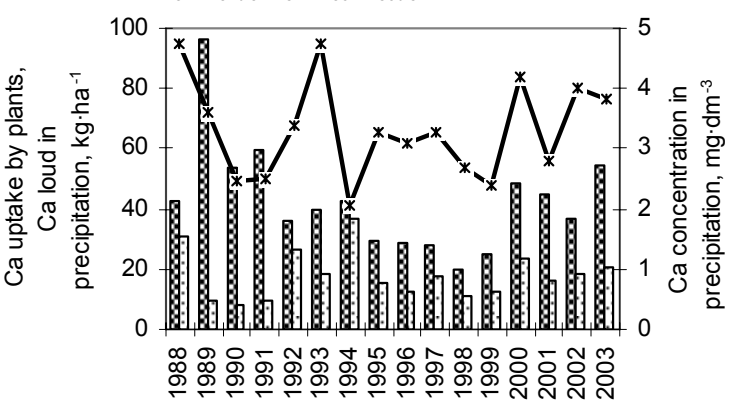

Years

$\ldots 00 \mathrm{Ca} 2 \quad-*-\mathrm{Ca} 1$

c)

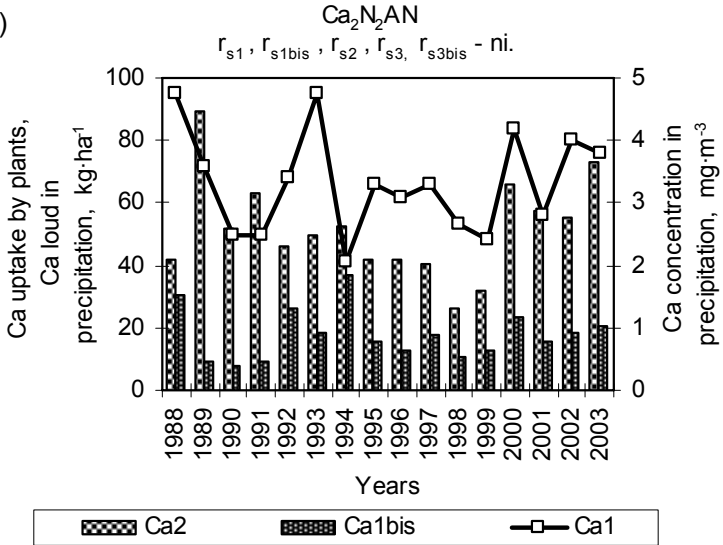

b)

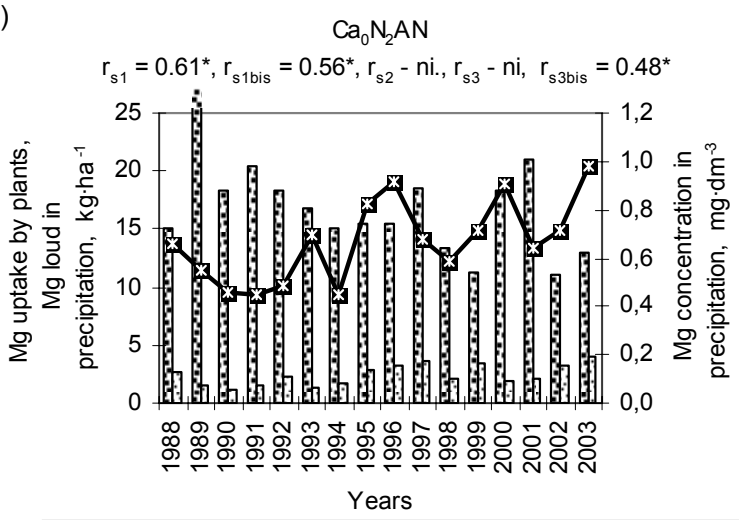

d)

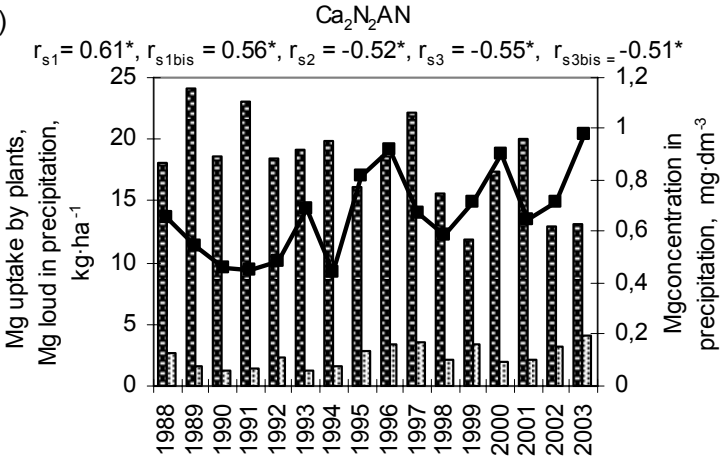

Years

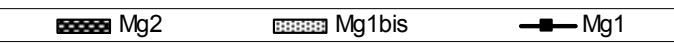

Fig. 1. Concentrations $\left(\mathrm{Ca}_{1}, \mathrm{Mg}_{1}\right)$ and loads $\left(\mathrm{Ca}_{1 \mathrm{bis}}, \mathrm{Mg}_{1 \mathrm{bis}}\right)$ of calcium and magnesium in atmospheric precipitation and their uptake by plants $\left(\mathrm{Ca}_{2}, \mathrm{Mg}_{2}\right)$ in fertilisation variants $\mathrm{Ca}_{0} \mathrm{~N}_{2} \mathrm{AN}(\mathrm{a}, \mathrm{b})$ and $\mathrm{Ca}_{2} \mathrm{~N}_{2} \mathrm{AN}(\mathrm{c}, \mathrm{d})$ of the experiment in Laszczki;

Spearman correlation coefficients: $r_{s 1}$ - concentration in precipitation x years, $r_{s 1 \text { bis }}-$ load in precipitation x years,

$r_{s 2}$ - uptake by plants x years, $r_{s 3}$ - uptake by plants x concentration in precipitation, $r_{s 3 b i s}-$ uptake by plants $\mathrm{x}$ load in precipitation

\section{RELATIONSHIPS BETWEEN CALCIUM AND MAGNESIUM UPTAKE BY PLANTS AND THEIR CONCENTRATION IN GROUND WATER}

Comparison of calcium and magnesium concentrations in ground water from under studied meadows shows a higher concentrations of these elements in the
Laszczki than in the Janki experiment (Tab. 7). The differences pertain mainly to magnesium concentrations. Temporal changes in the concentration of both elements in ground water in the years 1995-2003 were insignificant. However, some enrichment in calcium with time was observed in Laszczki (Fig. 2c).

Table 7. Mean $\mathrm{pH}$ and concentrations of calcium and magnesium in ground water an soil solution in meadow experiments

\begin{tabular}{|c|c|c|c|c|c|c|c|c|c|}
\hline \multirow[b]{2}{*}{ Sample } & \multirow[b]{2}{*}{ Experiment } & \multirow{2}{*}{$\begin{array}{l}\text { Fertilisation } \\
\text { variant }^{1)}\end{array}$} & \multirow[b]{2}{*}{ Years } & \multicolumn{2}{|c|}{$\mathrm{pH}^{1)}$} & \multicolumn{2}{|c|}{$\mathrm{Ca}$} & \multicolumn{2}{|c|}{$\mathrm{Mg}$} \\
\hline & & & & mean & $\mathrm{CV} \%$ & $\begin{array}{c}\text { mean } \\
\mathrm{mg} \cdot \mathrm{dm}^{-3}\end{array}$ & $\mathrm{CV} \%$ & $\begin{array}{c}\text { mean } \\
\mathrm{mg} \mathrm{dm}^{-3}\end{array}$ & $\mathrm{CV} \%$ \\
\hline Ground water & Janki & & \multirow{2}{*}{ 1995-2003 } & 7.5 & 4.6 & 64.2 & 16.8 & 6.15 & 26.6 \\
\hline Ground water & Laszczki & & & 7.6 & 3.7 & 93.1 & 22.4 & 14.0 & 10.7 \\
\hline Soil solution & Janki & $\mathrm{Ca}_{0} \mathrm{~N}_{2} \mathrm{AN}$ & \multirow{4}{*}{ 1996-2007 } & 8.01 & 2.9 & 74.8 & 20.7 & 17.5 & 53.1 \\
\hline Soil solution & Janki & $\mathrm{Ca}_{2} \mathrm{~N}_{2} \mathrm{AN}$ & & 8.01 & 3.3 & 94.9 & 16.0 & 25.8 & 43.0 \\
\hline Soil solution & Janki & $\mathrm{Ca} \mathrm{N}_{2} \mathrm{CN}$ & & 7.96 & 6.2 & 87.8 & 37.1 & 17.7 & 52.0 \\
\hline Soil solution & Janki & $\mathrm{Ca}_{2} \mathrm{~N}_{2} \mathrm{CN}$ & & 8.13 & 3.0 & 71.8 & 38.7 & 31.8 & 53.5 \\
\hline
\end{tabular}

Explanations: $\mathrm{Ca}_{0} \mathrm{~N}_{2} \mathrm{AN}, \mathrm{Ca}_{2} \mathrm{~N}_{2} \mathrm{AN}, \mathrm{Ca}_{0} \mathrm{~N}_{2} \mathrm{CN}, \mathrm{Ca}_{2} \mathrm{~N}_{2} \mathrm{CN}$ - variants in soil fertilised with $240 \mathrm{~kg} \mathrm{~N}$ in a form of ammonium saltpetre (AN) and calcium saltpetre $(\mathrm{CN})$, not limed $\left(\mathrm{Ca}_{0}\right)$ and limed $\left(\mathrm{Ca}_{2}\right)$ acc. to the hydrolytic acidity criterion $2 \mathrm{Hh} ; \mathrm{CV} \%$ - coefficient of variability.

${ }^{1)} \mathrm{pH}$ of soil solutions - mean value from the years 1997-2002.

An assessment of the relationship between calcium and magnesium uptake by plants and the study years in soils of extreme $\mathrm{pH}_{\mathrm{KCl}}$ (3.6 and 6.6-6.9) showed significant decrease of $\mathrm{Mg}$ uptake by plants in the Janki experiment in soil formerly limed and fertilised with calcium saltpetre $\left(\mathrm{Ca}_{2} \mathrm{~N}_{2} \mathrm{CN}, r_{s 2 \text { bis }}=-0.83^{* *}\right)$ 
a)
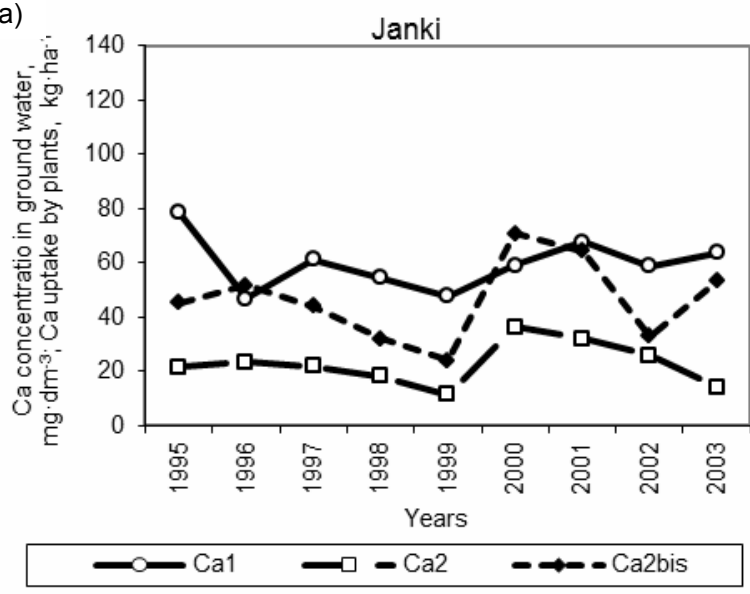

c)

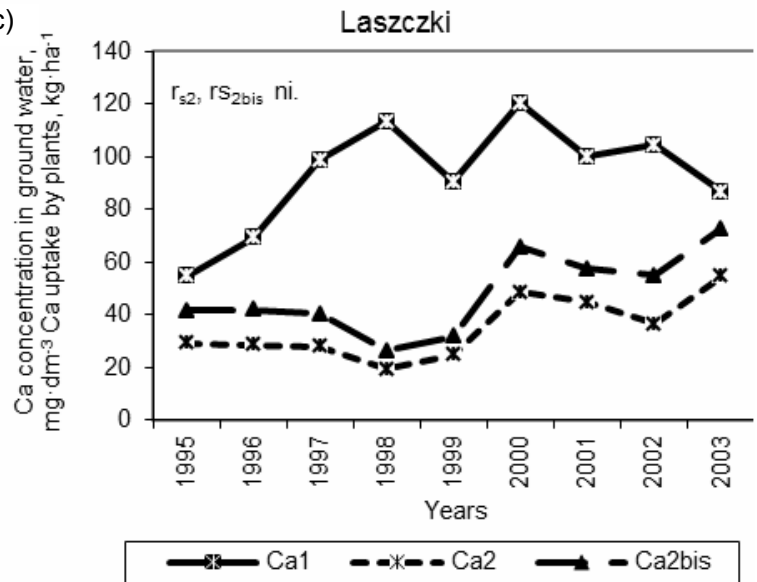

b)

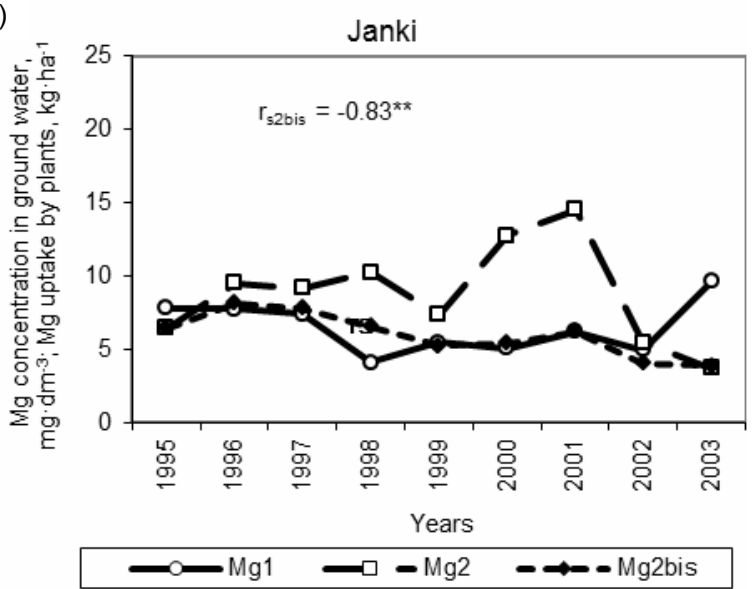

d)

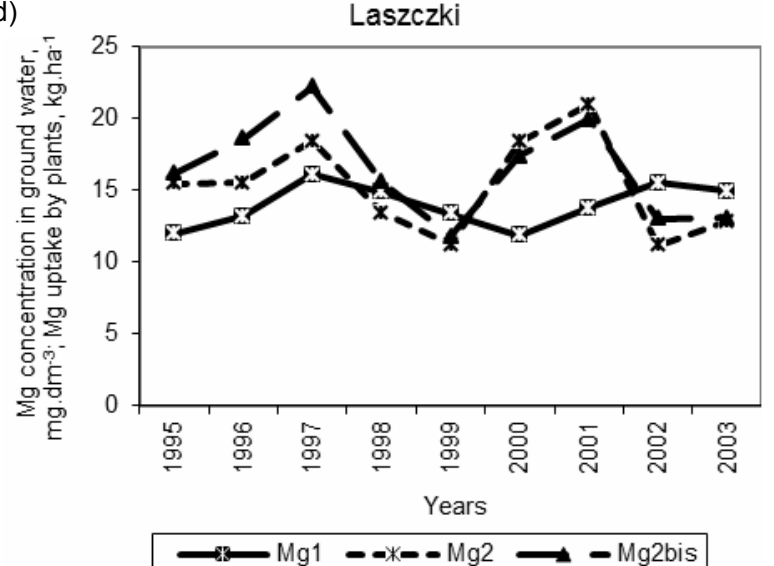

Fig. 2. Concentrations of calcium and magnesium in ground water $\left(\mathrm{Ca}_{1}, \mathrm{Mg}_{1}\right)$ and their uptake by plants in fertilisation variants $\mathrm{Ca}_{0} \mathrm{~N}_{2} \mathrm{AN}\left(\mathrm{Ca}_{2}, \mathrm{Mg}_{2}\right)$ and $\mathrm{Ca}_{2} \mathrm{~N}_{2} \mathrm{CN}\left(\mathrm{Ca}_{2 \text { bis }}, \mathrm{Mg}_{2}\right.$ bis $)$ of the experiment in Janki $(\mathrm{a}, \mathrm{b})$ and in Laszczki (c, d) in the years 1995-2003; Spearman correlation coefficients: $r_{s 2}$-years x uptake by plants from the variant $\mathrm{Ca}_{0} \mathrm{~N}_{2} \mathrm{AN}, r_{s 2 \mathrm{bis}}-$ years $\mathrm{x}$ uptake by plants from the variant $\mathrm{Ca}_{2} \mathrm{~N}_{2} \mathrm{CN}$

(Fig. 2b). Similar relationship was also demonstrated in the soil fertilised with ammonium saltpetre $\left(\mathrm{Ca}_{2} \mathrm{~N}_{2} \mathrm{AN}, r_{s 2}=-0.52 *\right)$ of the Laszczki experiment for the period 1988-2003 (Fig. 1d). A tendency for increasing $\mathrm{Ca}$ uptake with time was observed in objects of extreme soil $\mathrm{pH}$ in the Laszczki experiment but calculated Spearman correlation coefficients were insignificant $\left(r_{s 2}=0.62, r_{s 2 \text { bis }}=0.63\right)$ though close to the critical value $\left(r_{s}=0.64\right)$ (Fig. $\left.2 \mathrm{c}\right)$.

The relationships between calcium and magnesium uptake and their concentrations in ground water in both experiments were statistically insignificant. Lines of changes of studied relationships in compared fertilisation variants in soils of extreme $\mathrm{pH}$ values for both experiments showed mostly opposite direction for both calcium and magnesium (Fig. 2a, b, c, d). It would thus appear that with increasing $\mathrm{Ca}$ concentration in ground water one should expect its greater uptake by plants. However, increasing concentration of calcium in ground water could result from its washout from soil and from the enrichment by precipitation that contained substantial load of this element (Fig. 1a, c, Tab. 3, 4). Decreased Mg uptake by plants with increasing abundance of this element in ground water (particularly in the Janki experiment) would indicate its stronger than Ca washout from soil [GLIŃSKI 1999] (Fig. 2b, d). Much smaller Mg load in atmospheric precipitation could additionally deepen its deficit in the soil (Tab. 5, 6).

\section{RELATIONSHIPS BETWEEN CALCIUM AND MAGNESIUM UPTAKE BY PLANTS AND THEIR CONCENTRATION IN SOIL SOLUTION AND THE LOAD WASHED OUT FROM SOIL TO SOLUTION}

Results of analysis of soil solutions are from the Janki experiment. Changes of the mean Ca concentrations in solutions from $\mathrm{AN}$ and $\mathrm{CN}$ fertilised variants in the years 1996-2007 showed an increasing trend of this concentration with time (Fig. 3a, b). However, changes in the mean amounts of $\mathrm{Ca}$ taken up by meadow vegetation from these objects showed an opposite direction. It means that the lower $\mathrm{Ca}$ concentration in soil solution was accompanied by the greater Ca uptake by plants. Such a relationship was statistically verified only in $\mathrm{CN}$ fertilised variant $\left(r_{s 1}=\right.$ $-0.65^{*}$ ) (Fig. 3b). In contrast with calcium, magnesium concentration in soil solution at the AN fertilisa- 

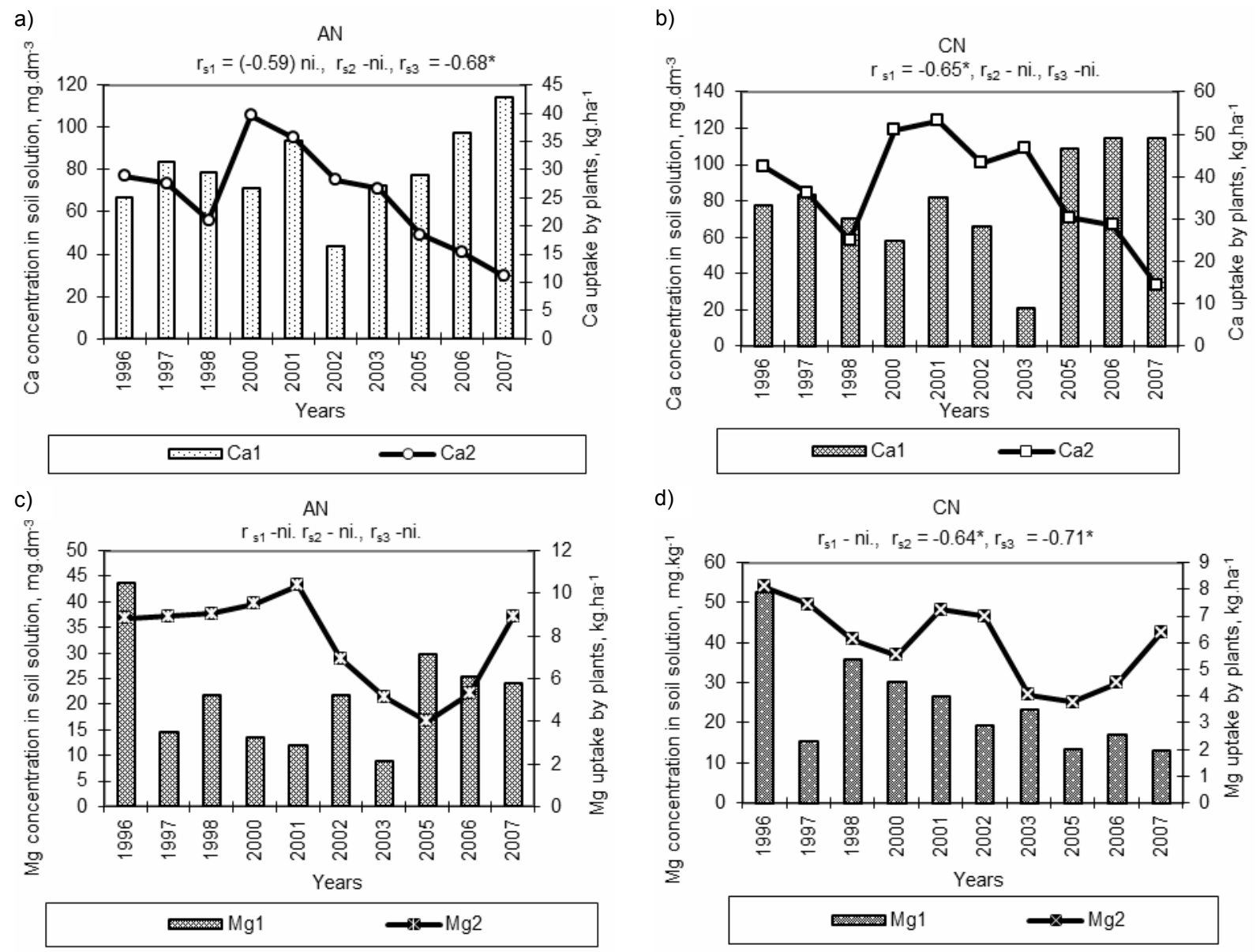

Fig. 3. Changes of the mean annual calcium $\left(\mathrm{Ca}_{1}\right)$ and magnesium $\left(\mathrm{Mg}_{1}\right)$ concentration in soil solution from objects fertilized with ammonium saltpeter $(\mathrm{AN})-\mathrm{a})$, c) and calcium saltpeter $(\mathrm{CN})-\mathrm{b})$, d) and their uptake by plants $\left(\mathrm{Ca}_{2}, \mathrm{Mg}_{2}\right)$ from the experiment in Janki in the years 1996-2007; Spearman correlation coefficients: $r_{s 1}$ - concentration in soil solution x uptake by plants, $r_{s 2}-$ concentration x years, $r_{s 3}$ - uptake x years

tion did not show clear trend of temporal changes. Fertilisation with $\mathrm{CN}$ facilitated a significant decrease of $\mathrm{Mg}$ in soil solution $\left(r_{s 2}=-0.64 *\right)$ and, consequently, a significant decrease of $\mathrm{Mg}$ uptake by plants $\left(r_{s 3}=-0.71 *\right)$. No significant relationship between $\mathrm{Mg}$ concentration in soil solution and $\mathrm{Mg}$ uptake by plants was, however, found at AN fertilisation (Fig. $3 c, d)$.

Since calculated loads of calcium and magnesium washed out to soil solutions represent only fouryear period (2000-2003), the changes and relationships between washout and uptake by plants were compared in soils of four objects differing in $\mathrm{pH}$ (Tab.1). Decreasing soil acidity $\left(\mathrm{pH}_{\mathrm{KCl}}: \mathrm{Ca}_{0} \mathrm{~N}_{2} \mathrm{AN}-\right.$ 3.6 $>\mathrm{Ca}_{0} \mathrm{~N}_{2} \mathrm{CN}-4.3>\mathrm{Ca}_{2} \mathrm{~N}_{2} \mathrm{AN}-5.0>\mathrm{Ca}_{2} \mathrm{~N}_{2} \mathrm{CN}-$ 6.6) was accompanied by a greater $\mathrm{Ca}$ uptake by plants and a smaller uptake of magnesium (Fig. 4a, b). This relationship was already found in earlier studies [SAPEK 2011]. Mean load of calcium washed out to soil solution was similar among study years despite differences in soil $\mathrm{pH}$. This could result in a similar and alkaline $\mathrm{pH}$ of soil solutions (Fig. 4a, Tab. 7). Under the same conditions a tendency of increasing Mg washout to soil solution was observed (Fig. 4b).
No significant relationship was found between $\mathrm{Ca}$ and $\mathrm{Mg}$ uptake by plants and their washout to soil solution $\left(r_{s 1}-\right.$ ni.) but the counteractive course of changes in the concentration of both elements would indicate that one might expect smaller Mg uptake by plants with decreasing soil acidity and consequently a greater washout of this element from soil (Fig. 4b). Performed assessment of studied relationships could have been affected by a low number of study years, more so that they involved a period of abandoned P fertilisation. Observed counteractive behaviour of the two elements confirms their environmental antagonism [GORLACH, MAZUR 2002]. Regardless of soil pH, however, increasing washout of magnesium loads to soil solution was accompanied by increasing amounts of washed out calcium, which was confirmed by significant positive Spearman correlation coefficient $\left(r_{s 2}\right.$ $\left.=0.55^{*}\right)($ Fig. $4 \mathrm{c})$ for the years 2000-2003.

\section{SUMMARY AND CONCLUSIONS}

Obtained results did not unequivocally show a positive effect of calcium and magnesium from atmospheric precipitation, ground water or soil solution 
on the uptake of these elements by meadow vegetation. From the load of $\mathrm{Ca}$ and $\mathrm{Mg}$ delivered to experimental meadow and from the amounts removed in dry mass of yield one may assume that systematic atmospheric deposition supplements nutrient losses from soils, especially calcium losses from acid soil not limed and fertilised with ammonium saltpetre. This may be evidenced by long persistent soil $\mathrm{pH}_{\mathrm{KCl}}=$

a)

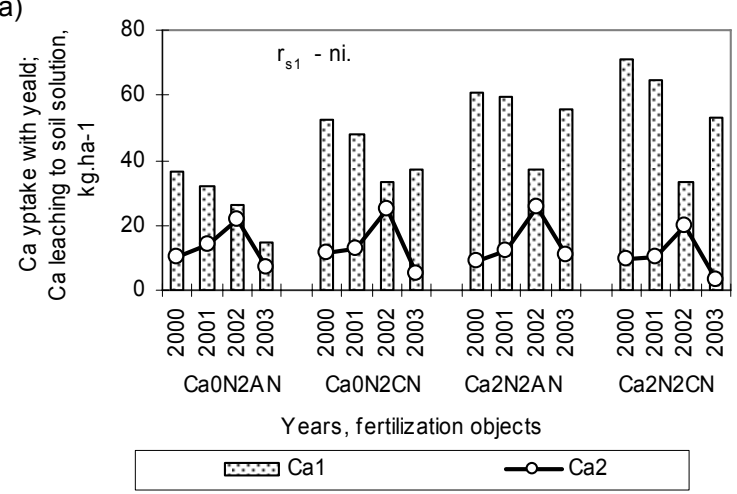

c)

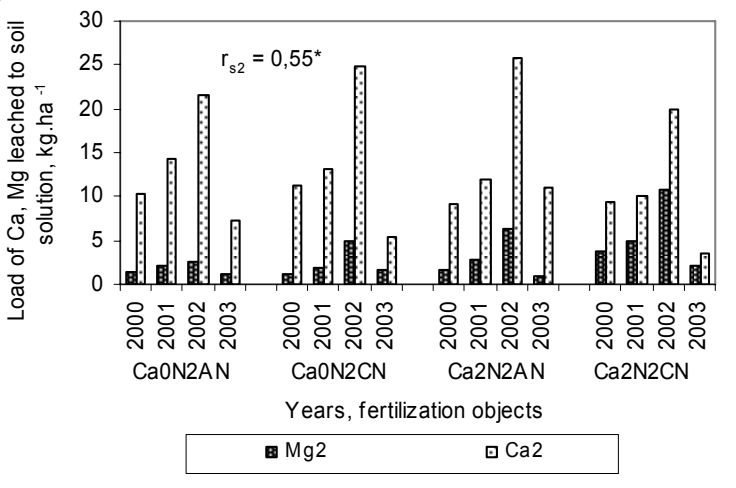

Results of long-term studies in permanent mown meadow on mineral soil presented in this study allow for the following conclusions:

- Substantial calcium deposit from atmospheric precipitation in Falenty constituting nearly $50 \%$ of the amount taken up by plants did not exert an unequivocal effect on long-term uptake at fertilisation with both ammonium and calcium saltpetre.

- In fertile soil of favourable physical and water conditions and slightly acidic $\mathrm{pH}_{\mathrm{KCl}}=5.8$ there was a significant, negative effect of the concentration and load of magnesium from atmospheric deposition on the uptake by plants and significant, positive effect of the load in strongly acid soil of $\mathrm{pH}_{\mathrm{KCl}}$ $=3.6$. This conclusion points to a complex process of mutual interactions between atmospheric $\mathrm{Ca}$ and Mg differing in solubility.

- Observed tendency of a positive effect of calcium concentration in ground water on its uptake by plants and of a negative effect on magnesium uptake in very acid soils of both experiments could be a result of ground water enrichment with atmos-
3.6 and its low variability (5\%). Such an effect demonstrated partly in this study operates in permanent, managed and fertilised meadows exemplified here by presented long-term meadow experiments. The effect is complex and much less visible due to fertilisation, harvesting, soil properties and other biological and anthropogenic factors.

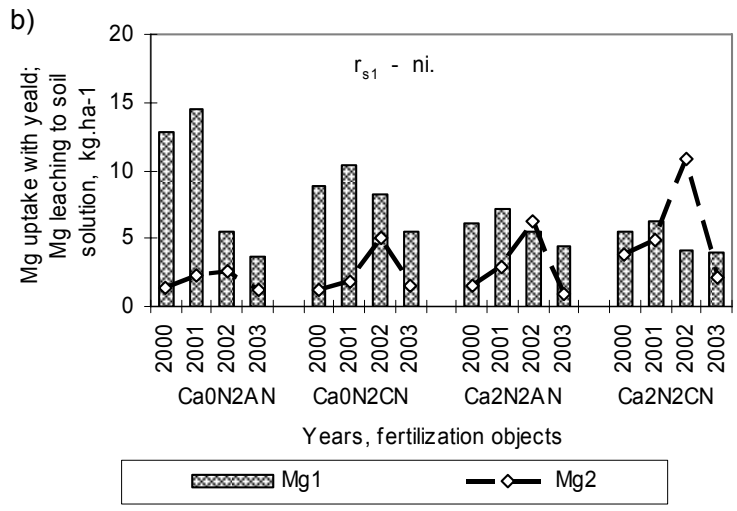

Fig. 4. Changes of annual sum of calcium $\left(\mathrm{Ca}_{1}\right)$ and magnesium $\left(\mathrm{Mg}_{1}\right)$ uptake by plants and their annual washout from soil to soil solution $\left(\mathrm{Ca}_{2}\right),\left(\mathrm{Mg}_{2}\right)$ in fertilisation variants $\mathrm{Ca}_{0} \mathrm{~N}_{2} \mathrm{AN}, \mathrm{Ca}_{0} \mathrm{~N}_{2} \mathrm{CN}, \mathrm{Ca}_{2} \mathrm{~N}_{2} \mathrm{AN}$ and $\mathrm{Ca}_{2} \mathrm{~N} 2{ }_{\mathrm{C}} \mathrm{N}$ of the experiment in Janki in the years 2000-2003-a), b), c); Spearman correlation coefficients of Spearman: $r_{s 1}$ - uptake with yield $\mathrm{x}$ washout to soil solution considering results from years and fertilization objects, $r_{s 2}-$ washout to soil solution $\mathrm{Ca} \times \mathrm{Mg}$

pheric $\mathrm{Ca}$ and, consequently, of limited $\mathrm{Mg}$ availability from this source for plants.

- Diminished uptake of calcium by plants in the study decade in acid soil poor in humus caused substantial enrichment of soil solution in this element, particularly at fertilisation with calcium saltpetre, and significant decrease of magnesium concentration in this solution.

- Soil neutralization facilitates the decreased $\mathrm{Mg}$ uptake by plants, which increases its washout from soil to soil solution. Irrespective of soil $\mathrm{pH}$, increasing calcium washout to soil solution is accompanied by magnesium washout with important contribution of atmospheric precipitation.

- Results obtained under conditions of experimental productive meadow inspire to undertake similar studies on the effect of atmospheric calcium and magnesium on their concentrations in soil waters and on the uptake by plants in natural meadow ecosystems and in lands of ecological use. 


\section{REFERENCES}

ARIANOUTSOU M. 1989. Atmospheric deposition of nutrients in a coastal maquis ecosystem of northeastern Greece. International Journal of Biometeorology. No 33 p. 124-130.

CHADWick O.A., DERRY L.A., VitouseK P.M., HuEBert B.J., HEMIN L.O. 1999. Changing sources of nutrients during four million years of ecosystem development. Nature. Vol. 397 p. 491-497.

Gorlach E., Mazur T. 2002. Podstawy żywienia roślin. Rozdział 2. W: Chemia rolna [Fundamentals of plant feeding. Chapter 2. In: Agricultural chemistry]. Warszawa. PWN p. 42-45.

GLIŃSKI J. 1999. Chemiczne i fizykochemiczne właściwości gleb. W: Gleboznawstwo. [Chemical and physico-chemical soil properties. In: Soil science]. Ed. S. Zawadzki. Warszawa. PWRiL p. 183-236.

HlawiczKa S., Dyduch B., Fudala J. 2003. Long-term changes of particulate emission in the industrial region of upper Silesia (Poland) and their effect on the acidity of rainwater. Water, Air and Soil Pollution. No 142 s. 151163.

JANKOWSKA-HufleJT H. 2009. Ocena wpływu nawożenia i dokarmiania dolistnego na wartość paszowa runi łakowej w świetle doświadczeń łanowych [An assessment of the effect of foliar feeding on fodder quality of meadow sward in view of meadow experiments]. IV Konferencja naukowa pt. Woda-Środowisko-Obszary Wiejskie. Falenty, 25-26 listopada 2009.

JonARD M., ANDrÉ F., DAMBrin E., PonetTe Q., UlRich E. 2009. Temporal trends in the foliar nutritional status of the French, Walloon and Luxemburg broad-leaved plots of forest monitoring. Annales of Forest Science. Vol. 66 p. $412(1-100)$.

KACORZYK P., KASPERCZYK M., SZEWCZYK W. 2012. Ładunek składników nawozowych wnoszony $\mathrm{z}$ opadem atmosferycznym na powierzchnię ziemi w rejonie górskim [Nutrient load deposited with atmospheric precipitation on the ground surface in a mountain region]. WodaŚrodowisko-Obszary Wiejskie. T. 12. Z. 4(40) p. 145150.

Pietrzak S., Urbaniak M., SaPeK B. 2006. Ocena zmian stężenia mineralnych form azotu $\mathrm{w}$ roztworach glebowych i ich wymywania [An assessment of changes in the concentration of mineral nitrogen forms in soil solutions and their washout]. Woda-Środowisko-Obszary Wiejskie. T. 6. Z. spec. (17) p. 51-64.

POTTER CH. S. 1991.Atmospheric deposition and foliar leaching in a regenerating Southern Appalachian forest canopy. Journal of Ecology. Vol. 79 p. 97-115.

PRUSIŃKIEWICZ Z. 2011. Roztwór glebowy i jego ekologiczne znaczenie. W: Badania ekologiczno-gleboznawcze [Soil solution and its ecological importance. In: Ecological and pedological studies]. P. XX. Warszawa. PWN. s. 234241.

SAPEK A. 1979. Metody analizy chemicznej roślinności łąkowej, gleby i wody. Cz. 1. [Methods of chemical analyses of meadow vegetation, soil and water. P. 1]. Falenty. IMUZ pp. 55.
SAPEK A., NAwALANY P. 2006. Ładunek składników nawozowych wnoszonych $\mathrm{z}$ opadem atmosferycznym na powierzchnię ziemi na przykładzie pól doświadczalnych w Falentach [Nutrient load delivered with atmospheric precipitation on ground surface based on the example of experimental fields in Falenty]. Woda-ŚrodowiskoObszary Wiejskie. T. 6. Z. 17 p. 23-28.

SAPEK B. 2006. Przedmowa. W: Azot, fosfor i potas oraz plonowanie trwałego użytku zielonego na długoletnich doświadczeniach łąkowych [Preface. In: Nitrogen, phosphorus and potassium and the yielding of permanent grassland in long-term meadow experiments]. WodaŚrodowisko-Obszary Wiejskie. T. 6. Z. 17 p. 5-13.

SAPEK B. 2011. Współzależność pobrania wapnia i magnezu przez roślinność lakową oraz ich wymywanie z gleby $\mathrm{w}$ wieloleciu na tle jej odczynu i formy stosowanego nawozu azotowego [Correlation between calcium and magnesium uptake by meadow vegetation and their washout from soil in a long-term study with respect to soil $\mathrm{pH}$ and the type of nitrogen fertiliser]. Zeszyty Problemowe Postępów Nauk Rolnczych. Z. 565 p. 237-252.

SAPeK B., Nawalany P., Barszczewski J. 2003. Stężenie składników mineralnych i odczyn wód gruntowych spod długoletnich doświadczeń łąkowych w Falentach [Concentration of mineral components and $\mathrm{pH}$ of ground waters under long-term meadow experiments in Falenty]. Woda-Środowisko-Obszary Wiejskie. T. 3. Z. spec. (6) p. 59-68.

SAPEK B., PIETRZAK S. 1996. Zastosowanie metody aparatów ssących z ceramicznymi kubkami porowatymi do oceny potencjalnego wymycia azotanów z gleb łąkowych. [Application of the method of suction apparatuses with ceramic pore cups in the assessment of potential nitrate washout from meadow soils] Zeszyty Problemowe Postępów Nauk Rolnczych. Z. 440 p. 343-352.

SAPEK B., SAPEK A. 2011. Wapń i magnez w opadzie atmosferycznym [Calcium and magnesium in atmospheric precipitation]. Ochrona Środowiska i Zasobów Naturalnych. Nr 50 p. 134-154.

SCHLESINGER W.H., GRAY J.T., GILLIAM F.S. 1982. Atmospheric deposition processes and their importance as sources of nutrients in a chaparral ecosystem of southern California. Water Resources Research. Vol. 18. No. 3 p. 623 doi: 10.1029/WR018i003p00623.

SKURZYŃSKI A. 2009. Dolistne dokarmianie roślin [Foliar feeding of plants]. [online]. Minikowo. Kujawsko-Pomorski Ośrodek Doradztwa Rolniczego, Oddział w Przysieku. Biuletyn Internetowy. [Access 10.03.2013]. Available at http://www.kpodr.pl/roslinna/inne/dolistne dokarmianie_roslin.php

SZPERLIŃSKI Z. 2002. Chemia wybranych elementów środowiska naturalnego. W: Chemia w ochronie i inżynierii środowiska. Cz. II, III [Chemistry of selected elements of the natural environment. In: Chemistry in environmental protection and engineering. P. II, III]. Warszawa. Oficyna Wydaw. PW p. 585-651.

WARCHOŁOWA M. 1976. Kationy dwuwartościowe. W: Fizjologia mineralnego żywienia roślin [Divalent cations. In: Physiology of mineral plant nutrition]. Ed. A. NowotnyMieczyńska. Warszawa. PWRiL p. 296-358. 


\section{Barbara SAPEK}

Pobranie wapnia i magnezu z plonem roślinności ląkowej na tle ich zawartości w opadzie atmosferycznym, wodzie gruntowej i roztworze glebowym

\section{STRESZCZENIE}

Słowa kluczowe: magnez, opad atmosferyczny, pobranie z plonem roślin łakowych, roztwór glebowy, wapń, woda gruntowa

Postawiono pytanie, czy, w jakich warunkach i w jaki sposób stężenie oraz ładunek wapnia i magnezu w opadzie atmosferycznym oraz w wodzie gruntowej i roztworze glebowym mogą wpływać na pobranie tych składników z plonem roślinności w warunkach użytkowanej łąki. Odpowiedzi na to pytanie poszukiwano na podstawie wyników oznaczeń $\mathrm{Ca}$ i $\mathrm{Mg}$ w opadzie atmosferycznym z rejonu Falent oraz w wodzie glebowej z dwóch długoletnich doświadczeń łąkowych na glebie mineralnej, usytuowanych w województwie mazowieckim. Na podstawie uzyskanych wyników badań stwierdzono złożony i uwikłany wpływ depozytu Ca i $\mathrm{Mg}$ z opadu oraz związane z nim oddziaływania tych składników w wodzie gruntowej i w roztworze glebowym na ich pobieranie z plonem z uwagi na działanie nawożenia, zbioru plonu oraz pozostałych czynników antropogenicznych. Nie stwierdzono jednoznacznie dodatniego oddziaływania zwiększenia ładunku Ca z opadu atmosferycznego na jego pobranie przez rośliny w wieloleciu. Wpływ taki wykazano w odniesieniu do ładunku Mg, lecz tylko na bardzo kwaśnej glebie. W korzystnych warunkach fizyczno-wodnych i słabo kwaśnego odczynu gleby ten wpływ był ujemny. Wzbogaceniu wody gruntowej w Ca towarzyszyło zwiększenie jego pobrania z plonem roślin i jednocześnie zmniejszenie pobrania Mg z gleby bardzo kwaśnej. W takich warunkach odczynu gleby zmniejszeniu pobrania Ca towarzyszyło większe jego stężenie w roztworze glebowym. Zobojętnienie nadmiaru kwasowości gleby sprzyjało zwiększeniu stężenia Mg w roztworze glebowym i mniejszemu jego pobraniu przez rośliny. Uzyskane wyniki inspirują do podjęcia podobnych badań w warunkach naturalnych ekosystemów łąkowych i tzw. użytków ekologicznych. 